\title{
Masculinity, Disability, and Politics in Polish War-Disabled Memoirs (1971)
}

\author{
Wojciech Śmieja
}

\begin{abstract}
This article offers a contextualized analysis of disabled Polish war veterans' memoirs published in 1971. This set of documents constitutes a remarkable source for understanding how masculinity and male corporeality are narrated and negotiated between politics, social and family lives, private and public spheres. The article focuses on the conventions and conditions of war-disability discourse production in Poland during the long sixties; it also highlights biographical tensions between appreciation of veterans' masculinity in political discourse and their often emasculated position in social structures, families and private lives.
\end{abstract}

KeYwORDs: disability, masculinity, memoirs, state socialism, war-disabled veterans

Tadeusz Konwicki's ${ }^{1}$ best-selling novel Sennik wspótczesny (A dreambook for our time) ${ }^{2}$ presented, among other characters traumatized by the war experience, the figure of the Partisan. The Partisan is a war-disabled person who is trying, without success, to seduce a sexually attractive girl, Regina. To gain her sexual interest, the Partisan exposes his prostheses, but his wounds and artificial limbs disgust the girl rather than attract her attention: Regina evades him, yet he seems to be unable to understand her lack of interest and her revulsion.

In his surrealistic novel, Konwicki manages to grasp the confusing position of wardisabled veterans in state-socialist Poland: official discourse celebrated war-disability as a sacrifice on the altar of freedom and nationhood, while the everyday life of disabled veterans was harsh and often marked by incomprehension, disregard, or even hostility.

The three fundamental myths (victory over fascism, national unity, and generalized martyrdom) of Polish "martial patriotism" ${ }^{3}$ converged in official representations of the disabled bodies of war veterans under state socialism. War-disabled veterans also embodied another important political myth: the myth of the new strong socialist masculinity, able to overcome physical handicaps and institutional shortcomings 
with discipline, diligence, and mental strength forged by and in the course of military service.

Konwicki's Partisan embodies and believes in these ideals; he is convinced that his impaired body distinguishes him as a man. Regina should be sexually interested in his wounds as signs of masculinity and his privileged social position, while in fact Regina's reaction reflects an important social process named by Polish sociologists as the "decade of the twilight of the elderly."4 The younger generation refused to uphold the ideas of their elders, who often assumed that their war experiences entitled them to impose their set of values on the younger generations. In other words, the combatant dividend (a term inspired by Raewyn W. Connell's the patriarchal dividend ${ }^{5}$ ) was diminishing rapidly and this trend had great impact on gender norms. As Natalia Jarska argues, during the 1960s and 1970s, the postwar generation in Poland actively negotiated gender roles in private lives, questioned traditional masculinity, and shaped new understandings of men's roles based on ideas of companionship and partnership. ${ }^{6}$ These new understandings directed men toward assuming selected female tasks and the gradual erosion of traditional military-based models of masculinity celebrated and supported by the regime.

Konwicki's story is purely fictional, and we have very limited access to personal reflections on the disability of disabled war veterans themselves under Polish state socialism. ${ }^{7}$ We know little about the way they narrated their situation in egodocuments, on whether and how war injuries became a source of personal pride, and to what extent disability was a source of stigma and hostility, a visible sign of otherness or emasculation. This article aims to reconstruct the conventions and conditions of war-disability discourse production in Poland during the "long sixties." Examining the very rare ego-documents of war-disabled veterans (the collection Pamiętniki inwalidów wojennych [War-disabled memoirs], edited by Henryk Gaworski and published in 1971 by the Polish Ministry of Defense Publishing House in a run of 10,000 copies) ${ }^{8}$ we will see how these discourses were constructed, what the limits were of sincerity in the public sphere, how private and intimate experiences became political, and what was allowed in discussions of war disability and what was avoided. This collection of memoirs is unusual: on the one hand, it allowed the expressions of personal and intimate experiences (subjectivities) of the war-disabled; on the other hand, the memoirs had to respect the political agenda and reproduce narrative schemes elaborated in Soviet-style socialist realism and accepted by the Party.

\section{Reading the Memoirs: Style and Conventions}

The early postwar years were particularly harsh for veterans as state support was scarce and appropriate veterans' institutions were in the process of organization; thus, the period between 1944 and 1949 is described as a period of samopomocowy (selfhelp). ${ }^{9}$ It was followed by Stalinization, which lasted from 1949 to 1955, and was characterized by the unification of institutions and strict state control of associations and cooperatives formed by war-invalids. The number of active members of war veterans' organizations diminished rapidly. ${ }^{10}$ The third period began with the Thaw in 1956 
and lasted until 1970. It was characterized by the development of legal permissions and privileges awarded to the war-disabled. The disabled were allowed to have better provisions, rehabilitation, access to job opportunities (many disabled cooperatives were formed then), medical support, etc. After 1966, the victims of Nazi concentration camps shared the same privileges as frontline veterans. The years 1971-1989 formed another period in the history of war-disabled veterans. In 1972, a new Veteran's Office was established as a sign of appreciation of the veterans' role in society. Soon after, a report on the situation of veterans was prepared for party and state authorities. The report presented the material and demographic situation of war veterans, whose number had begun to diminish due to natural causes. Its publication was the first step toward enacting new legal regulations in 1974 to address the situation of disabled veterans, providing veterans with further material support and medical care particularly needed among this aging population. ${ }^{11}$

Undoubtedly, this collection of memoirs, which appeared at the turn between third and fourth stage, openly broke with the postwar tradition of presenting disability in a non-personal way, as a social problem and a matter for organized structures (veteran associations, political activism). Indeed, as Lucyna Ratkowska has demonstrated in her analysis of press materials concerning war-disability, in the early postwar period, the war-disabled themselves were not the focus when the issue of war-disability was discussed; greater attention was given to war veterans' organizations and the disabled in general. ${ }^{12}$ This orientation changed by the early 1970 s.

The publication of War-Disabled Memoirs was the result of a literary contest announced by the Ministry of Defense and was aimed at "personalizing" the experience of disability and, thus, filling the discursive gap by presenting a set of private memoirs reflecting the experience of being a war-disabled veteran. The contest was announced in the late 1960s by Związek Inwalidów Wojennych (The Association of War Invalids) among its members. The majority of the authors whose texts were ultimately published were middle-range state functionaries (lawyers, semiprofessional writers, teachers, officials, etc.) and active supporters of the political regime. The political criteria for these selections are rather obvious. The texts had to present a "positive" narrative of the disabled veteran, a man who, even facing numerous obstacles, had succeeded in the new state socialist reality (some authors even highlighted the fact that their disability became an opportunity to get a university degree and thus, paradoxically, war wounds ameliorated their social status). ${ }^{13}$ The editor of the volume, Henryk Gaworski, was responsible for its orthodoxy and political line. He was a second-rate writer, a loyal party member, and a secret services informer in literary circles known for his devotion to the most radical nationalist group within the Party ("Moczar's circle"), a very outspoken anti-Zionist and party "falcon."14

When assessing the collection, one must be aware of two important literary and social elements shaping the memoirs. The first consists of the typical features of the genre and the second is the political context of the publication. Regarding the genre, Małgorzata Szpakowska, in her cultural analysis of everyday Polish life in the 1960s, noted that "thematic literary contests blossomed among Polish newspapers and magazines that prompted their readers to write memoirs about their ideas of love, marriage or parenthood, etc." 15 There is no doubt that the memoirs of the war-disabled 
were born of this trend; ${ }^{16}$ the book was the result of one such contest, organized under the auspices of the Ministry of National Defense. For this reason, the memoirs reproduced many of the conventions typical for such texts, including the valorization of the individual perspective and private experiences; complaints; confessions; first-person narratives; and attempts by authors to understand their own social position. ${ }^{17}$ It is worth noting, however, that the Ministry by no means intended to produce a documentation of the rapid social changes of post-Stalinism, as was the aim of the more than thirty contests organized by the popular press, weeklies and monthlies Tygodnik Powszechny (The Catholic weekly), Argumenty (Arguments), Tygodnik Kulturalny (The cultural weekly), Życie Warszawy (Life of Warsaw).$^{18}$ On the contrary, this contest placed great emphasis on the preservation of martially informed masculine ideals as a highly praised and valorized category, but to reach this general aim, the organizers had to take new conventions and changing social expectations into account. Their conservative attitude was similar to that present in post-Thaw Soviet movies described by Claire McCallum, which "for the first time began to explore themes such as the emotional impact of separation, homecoming and the disruption to the normal life course that war had caused." 19

The publication of War-Disabled Memoirs, with their personal format, was intended to offer an intergenerational exchange of emotions and moral attitudes. The collection adapted the popular memoir format to meet the expectations of potential younger readers, while the authors were elders entrusting a set of important values to their heirs. Gaworski, in the "Foreword," directed his comments in particular to "the reader interested in our national history, especially the young one." He continued: "The collection represents the arch of the alliance between past and present times evoked by Adam Mickiewicz; it is a strong and wide bridge between fathers, who fought for independence, and sons and daughters, who are obliged to develop and ennoble this precious heritage." 20 The universalized masculinity of "the fathers" contributed to establishing a model of identity that transcended social, educational, and cultural limits with one important exception: gender. Seventeen out of the 18 published memoirs were written by men, and reflect men's lives and experiences. One memoir is the story of a woman concentration camp prisoner, Jadwiga Iwańska, the mother of two sons, who reported her struggle to keep herself and her sons alive in harsh camp conditions. Her memoir is the only one that does not refer to the battlefield and/or direct military experience, but, as camp victims had the same status as war-disabled veterans after 1966, her presence is justified. Her experience does not challenge David A. Gerber's observation that "the disabled veteran written about is always 'he,' for women have been infrequent and statistically underrepresented participants in Western national armies, and have rarely served in active roles in such forces, though serving with distinction at times." 21

In Gaworski's "Foreword," masculinity is a self-evident, universal, yet invisible (or perhaps merely transparent) value. The frontline experience created a particular sense of brotherhood between men and was a premise to establish the masculinity of the disabled veteran as a common denominator for the entire group of men. In the Polish lexical idiom of the 1960s-1980s, there was even a word, zbowidowiec, to name a member of such group: "The war-disabled do not form a particular social or profes- 
sional group; they represent a wide variety of interests, have different backgrounds, and represent various worldviews. Some are workers; others are attorneys, peasants, teachers, doctors, clerks, craftsmen, or pensioners. What makes these memoirs so unusual and unique does not consist in intellectual, professional, or social differentiations, but in the particular social position of the authors [as war-disabled]."22

Małgorzata Szpakowska has cautioned that the authenticity of personal documents is limited by the active presence of institutional censorship, self-censorship by authors, and authors' reluctant attitude toward "ideological declarations and statements concerning public issues."23 Szpakowska further notes that "in the 1960s, writers were allowed, for the first time after the war, to write about private life and interpersonal relations without being blamed for bourgeois individualism. On the other hand, many interesting and vital issues were still silenced or tabooed."24 Both censorship and self-censorship (manifesting, for example, in an absence of references to the Church, the Holocaust, anti-communism, or harsh difficulties of early postwar years) are obvious in Gaworski's collection, which has to be understood in the wider context of political propaganda. However, contrary to the trends that dominated in other memoir contests (in the memoirs of teachers, young farmers, doctors, newlyweds, etc.), its political dimension was accentuated: the authors freely expressed their social and political positions as members of a socialist society, their activity within its organizations, and/or their participation in party activism. Some of them even seemed eager to deliver their ideological declarations: "As a war invalid, I am not only absorbed by my professional life, but I'm an active member of different NGOs. I am the head of the Local Association of War Invalids and I have been holding the position of the Secretary of the Party in my workplace for 20 years." 25

Others proudly enumerated the medals and merits they received as signs of honors and legitimate position in society. ${ }^{26}$ Complaints or remarks criticizing the regime were rare. One of the authors, Tadeusz Mazur, when recalling the late 1940s, blamed the local communist party authorities for a lack of support. His critique concerned the pre-Thaw period of "errors and distortions" and as such was accepted in public discourse during the 1960s: "The first secretary [of the local committee] answered that he could not help me and informed me that the Party would not be abused in that way! I really could not understand him. When I angrily told him what I actually was thinking about his lack of moral quality as a Party member, he threatened me that he would call the Secret Police (Urząd Bezpieczeństwa)." ${ }^{27}$

Traditionally, scholars have argued that the Polish variant of Socialist Realism reigned in literature for a relatively short period (and ended definitively with the Thaw in 1955/56). ${ }^{28}$ Polish Socialist Realist literature was highly derivative and copied the forms developed in the Soviet Union. Zbigniew Jarosiński calls it, simply, "transplantation." 29 The typical plots were dominated first by the reconstruction of industry and the six-year plan; second, by the collectivization of farming; and third, by pre- and postwar political shifts. ${ }^{30}$ Yet, Polish Socialist Realism did not bring about the types of inspiring novels on disability seen within the Soviet Union, which featured quintessentially positive heroes such as those found in Boris Polevoy's The Story of a Real Man or Nikolai Ostrovsky How the Steel Was Tempered. Claire McCallum, while summarizing the research of Lilya Kaganovsky ${ }^{31}$ and Anna Krylova ${ }^{32}$ in the field, has even argued 
that "the disabled man in Stalinist culture was just as much an ideal as the Stakhanovite." 33 Both the fictional figure of Korchagin (Ostrovsky), and the real figure of Maresyev (Polevoy), were well and widely known to the Polish public at the time thanks to translations, numerous editions, film adaptations, and required reading assigned in schools. Various Polish magazines and newspapers also commented on Ostrovsky's novels. ${ }^{34}$ Nevertheless, a similar figure of local origin was missing in the cultural horizon of the epoque. The analyzed volume of memoirs thus could be interpreted as a belated attempt to adapt this ideal of a disabled man devoted to his Motherland. The memoir authors were influenced by these widespread Soviet hagiographic narratives centered on disability. The Soviet-imported narratives had a normative function and served as examples for the authors in narrating their autobiographical sketches.

The reconstructed formula of the biography in the collection was as follows: mobilization, fight against the Nazis, injury and shock, hesitations and/or resignation, partial recovery of the physical ability, professional training as the beginning of a new life, work and service for the sake of the socialist society and the state with the triumph of will over the impaired body. The cultural influence resonated in the general features of the texts, which repeated the same story of a successful invalid, who, against all odds, continued his struggle for the sake of the socialist society. One of the memoirs, authored by Jerzy Hejduk, refers to Soviet literature more explicitly-even its title is identical to Mikhail Sholokhov's famous short story "The Fate of Man" (Los człowieka, filmed in 1959 by Sergei Bondarchuk). Another author admitted being influenced by the example of Soviet comrades: "At the beginning, I couldn't believe [that he could get full recognition as a useful member of the society], but when the hospital staff organized professional courses and many of my Soviet comrades attended them successfully, I began believing that I could get adapted to normal life." 35

Overall, the final shape of these narratives is located between "narrative prostheses" 36 offered by popular Soviet templates (Polevoy, Ostrovsky) and typical features of memoirs published in the popular press in 1960s Poland. The literary construction is thus hybrid: the personal experiences reported in memoirs fulfilled demands of the general narrative scheme adapted from literary sources and their propaganda use. Another issue influencing the way that war-disability was represented in public were political conditions: censorship and authors' active political acceptance of the political regime.

\section{Reading the Memoirs: The Political Context}

While interpreting these memoirs, the wider political context of the period must also be considered: the beginning of this (post-Stalinist) period in Poland is known as the "Little Stabilization" (1957-1963), but in fact, the whole period was marked by rapid social changes (the Thaw, demographic boom, urbanization, industrialization). After 1963, a political struggle within the Polish United Workers' Party (PZPR, Polska Zjednoczona Partia Robotnicza) between devoted orthodox internationalist-communists and nationalist-communists (called "Moczar's circle" or "the Partisans"), profoundly impacted internal politics. The nationalist wing within the Party, along with its potent proponent, Mieczysław Moczar, is particularly important, as Moczar was simultane- 
ously the head of the Ministry of Internal Affairs and of the organization constituted by and representing both war veterans and disabled veterans (Związek Bojowników o Wolność i Demokrację [Society of Fighters for Freedom and Democracy], ZBOWID, an official state-controlled veterans association directly subordinate to the Party). During the 1960s, the faction of the Party led by Moczar came to prominence and sought legitimization through the cultural dominance of "martial patriotism." Moczar believed that communists, especially those of Jewish origin, who had spent the war years in the Soviet Union, had played down the role of the communist guerillas who proved their political devotion and Polish patriotism under Nazi occupation. Only Poland-based communists had real war experience as guerillas, soldiers, or conspirators, he argued, while the Soviet-based group were mainly civilians and kept far from the dangers of frontline experiences. Moczar's group deliberately played this card in their political poker, believing that the shared experience of war and occupation legitimized his group in the eyes of the nation. When Moczar became Minister of the Interior he was able to take the conflict beyond the narrow confines of PZPR debates. To reach his aims he initiated an active cultural politics that focused on the activities of wartime communist partisans glorified in books and films. He also reached out to ex-combatants whose achievements had not yet been acknowledged, most obviously the Armia Krajowa (AK, the Home Army) and those who had fought in the west. ${ }^{37}$

The publication of War-Disabled Memoirs occurred in this context as one of the gestures aiming at winning veterans' support and consolidating them around the nationalist wing (the Partisans). "The Partisans" tried to impose upon the whole society their vision of history, culture, and morality. They cunningly inspired the politics of memory based on the three intermingled fundamental myths: of victory, of unity, and of innocent victims and nationalist martyrdom. ${ }^{38}$ The myth of victory over fascism was foundational to all state-socialist countries, including Poland. While in the 1950s this myth had had a very exclusive character limited to Soviet-commanded troops and guerillas, the politics of the 1960s attempted to make it truly inclusive. The nationalistcommunists were very active in promoting nationalist and militaristic values, as Moczar believed he could use them to establish the social basis for his ambitious political aims. Historians even claim that a new myth, the myth of unity, was created. This new myth encompassed the Soviet-commanded General Berling troops, communist guerillas, Home Army soldiers, Polish troops under Western command, concentration camp victims, and others, all of whom were gathered into one political teleology embodied by the Socialist People's Republic. ${ }^{39}$ This myth of unity was an interesting and unique trait of Polish memory politics in the 1960s; it demonstrated that along with the erasure of political differences (including the overt anti-communism of the troops who fought under the command of the Western Allies, or within the Home Army), the effort had a broader target: the independence of the state and deep reconstruction of a classless society unified by socialist ideology. These two myths were created alongside the myth of innocent victims and national martyrdom, which served to neutralize the historical fact that a significant number of Poles profited from, and actively supported, Nazi policies toward the Jewish minority (the topic of Polish perpetrators and active support of the Nazis in the Holocaust has been more openly discussed since the beginning of the twenty-first century ${ }^{40}$ ). 
The selection of texts published in Gaworski's collection fulfilled the demands of the abovementioned myths, and the editor took care to frame the collection in that light. The collection consists of eighteen memoirs. They tell the story of victory over Nazi Germany; the most-favored topics are a military operation in Pomerania (four texts) and the Winter Offensive of 1945 . The myth of unity resonates in the architecture of the entire volume, which contains the memoirs of a September 1939 campaign soldier, stories by partisans, the reminiscences of an anti-communist Home Army member, a sailor's narrative, and the stories of soldiers who served under General Berling and General Anders (communist and anti-communist, respectively). The myth of unity is expressed primarily in the way the collection as a whole asserts the leading role of communism and the Soviet Union. One of the authors (a soldier of the anti-communist Home Army) describes his initial distrust before he accepted the postwar political status quo as historical necessity: "The day of liberation was approaching, but we were increasingly confused. We knew almost nothing about the Soviet Union or the Red Army. Our prewar education, as well as the experience of occupation, inspired our reluctance and lack of confidence toward the first socialist country in the world; the political void we lived in made us unable to do anything." ${ }^{41}$

The third and final myth, the myth of victimhood and martyrdom, is particularly strong within the collection. Its articulation is embodied in personal narratives:

I became an invalid when I was 20, with no professional training and life perspectives. I could not accept that for a long time, and I often thought about suicide as a solution. ${ }^{42}$

Or another example:

I had always wanted to become a famous sportsman. I started out in my childhood by practicing different sports, imagining myself as an Olympic champion and medalist. Unfortunately, a bullet made this scenario impossible. After the war, my injured knee forced me to give up the idea of becoming a professional sportsman; I had to find a different way of serving my country in the field of sport. ${ }^{43}$

These three myths unite the combatants' stories and provide a foundation for their "male-centric" ethos grounded in war and occupation experience. As historian Joanna Wawrzyniak notes: "Former soldiers embody a very specific category within state policy - they bring together the dead and the living," ${ }^{44}$ and "soldierly front experience against death and injury ground the view that male homosocial groups sharing the same spirit, spilling blood, are the only proper forms of organizing society after the defeat." ${ }^{45}$

What Wawrzyniak argues about homosocial combatant groups is equally applicable in discourses of war-disability in communist Poland. Moreover, the general tendency within the politics of memory and, more broadly, official culture, was to keep the memory of the war experience militarized and thus masculinized. The situation reached its zenith and then began to change after the 1970 publication of the best- 
selling and widely discussed Pamiętnik z Powstania Warszawskiego (A memoir of the Warsaw uprising) by Miron Białoszewski. These discussions opened a path for reclaiming a more "civilian" form of remembrance with appreciation of different social groups (civilians, women, Jews, etc). Białoszewski's Memoir for many readers and critics was unacceptable: "focusing on the mundane details of the everyday life of civilians and giving up on the pathos of the great national sacrifice felt like a betrayal of patriotic ideals," ${ }^{\prime 46}$ but his fact-based novel was the first of a huge wave of books, articles, and memoirs that aimed to demythologize the memory. ${ }^{47}$ It is symbolic that the Moczar group, soon after they reached the peak of their influence, lost much of their political significance, and a new generation of party leaders, led by Edward Gierek, strived after 1970 to marginalize the Moczar group's political and cultural influence (for example, Gaworski became editor-in-chief of a relatively unimportant monthly magazine).

Gaworski's foreword linked war-disabled biographies with the fate of the state and the nation, where disability becomes a "gigantic metaphor" for the whole society:

None of the authors declares himself or claims to be a hero, although their ordinary military service-as is the most accurate term to describe their duty-is marked by heroic deeds. ... It is probably the war-invalids who most directly and convincingly link their service during wartime and afterwards with one moral and social obligation. ... There is no other nation, except the greatest imperial nations, that has participated in so many geographically dispersed battles, no other nation has made such a huge sacrifice. ${ }^{48}$

Thus, the insights derived from the biographies of disabled veterans served as exemplary pars pro toto of the postwar traumatized masculinity of Polish men in general. The active support of political regime and personal successful adaptation of disabled veterans were presented as desired forms of citizenship and the strong, respectable, reborn masculinity of the new socialist man.

\section{The Fourth Myth: Heroic Anti-Heroism in the Memoirs}

Gaworski stressed an antiheroic attitude as a defining element of the memoirs, both in terms of the poetics and the ethics of the authors. "Ordinary military service," was a form of "heroic anti-heroism," an important distinction for the ideology developed by Moczar's circle. The ideological explanation for their political views was presented in the writings of Colonel Zbigniew Załuski, "an essayist in battle dress." His main arguments were based on negating "the false opposition between Poland, the country of fighters, and Poland, the country of workers, between the military men and the working masses." ${ }^{49}$ The Partisans' political agenda took for granted the view that "the Partisans" were the only real heirs of the "true" popular military tradition stretching back to the medieval past. Such an agenda contained a discrete critique of "the communist-internationalists," whose civilian experience in the Soviet Union during the war years separated them from the "real" experience of Nazi occupation. Moczar's 
men also declared that "the Party Central Committee should be dissolved and replaced by a purely Polish body,"50 as anti-Semitism, however officially silenced, was strong ideological glue for the group and a source for wide political legitimization. This ideological thesis was supported and expressed in numerous ways in this collection, following this general line: imagined continuity linked contemporary work for the sake of the socialist state and the military and revolutionary struggle of past generations. Such was the directive formula presented by the editor of War-Disabled Memoirs: "It is all about proving to oneself-and to the whole world-the meaning, usefulness, and sense of one's existence. This can be attained only through hard work. Work has been an internal necessity for the authors of memoirs; it is a moral duty in exactly the same way as the fight against the Nazis was a necessity and a duty during the war." 51

This imagined continuity was best highlighted in the memoir authored by Tadeusz Fudała, titled Czas pracy, czas walki (The time of struggle, the time of work); another, by Bronisław Kruczko, quoted the nineteenth-century national poet, Cyprian Norwid, known for his celebration of the value of work. His seminal verse served as Kruczko's memoir title: Praca-by się zmartwychwstawało (Work-for resurrection). The imperative of fight-as-work was conceived as the axis for each story of the collection, part of the structure embodying the "normative" biography of a war-disabled veteran. Each biography on its own and the collection as a whole created a universal and desirable model of citizenship in classless socialist Poland, where civic and military, democratic and hierarchical values were intentionally blurred, but all were rooted in the ethics of duty that affirmed battlefield experience as the extreme sacrifice.

Everyday life was celebrated as the heroic struggle to overcome one's own limitations, and military service, in its turn, was presented as simple duty and hard work devoid of heroism. In a romanticized sense, heroic deeds, impressive but futile and ineffective, were associated with recklessness, bravado, and the audacity of the noblemen, while hard work was a value represented by the people, especially men, who were traditionally responsible for family well-being. The value of work was an essential feature of communist ideology as a whole, but in the context of disability, work became also a remedy for physical impairment.

Blurring the definition between military struggle (meant to be seen as an ordinary task) and work (characterized now as a constant struggle) was intended to erase the long-lasting social distinctions between noble bellatores and laborious laboratories - between the noblemen and peasants. This fundamental opposition of the feudal world-pany vs. chamy (masters vs. serfs) ${ }^{52}$ - was erased after 1944 with the land reforms initiated by communists, presented as a milestone achievement of the new political authorities. Postwar agrarian reform, together with newly installed economic and social systems, aimed at crushing the Polish "leisure class," along with its ethics, belligerent nationalism, codes of honor, destructive political alliances, norms of gender behavior, and more. The newly reconstructed masculinity imposed on men the obligation to devote their life to rebuilding and work, not to damage or destruction. War was justified only as a means of self-defense and the socialist state tied its legitimacy to its image as a guarantor of the peaceful coexistence of states and nations. ${ }^{53}$ This message was symbolically described in one of the memoirs. Its author, a soldier in 
the Home Army (which was both anti-Nazi and anti-communist) who had taken part in the Warsaw Uprising, accepted the new communist rule after the war and expiated his political mistake of anti-communism, which led to the tragedy of Warsaw Uprising in 1944. His transformation is illustrated by an uncanny incident he experienced after returning to the same place after eight years: "September 1952 was a 'month of reconstruction for our capital.' Together with 140 other teachers, I was removing debris in Solec [one of Warsaw's districts]. Coincidentally, I was working with my shovel and pickaxe in the same place I had discovered a Nazi machine-gun position in 1944. My brigade had fired upon this position, reducing the building to ruins, the same ruins I was trying to put in order now." 54

The reconstruction of the capital was of particular importance in communist propaganda. It legitimized the new political regime and was meant to unite the whole nation around one universally accepted aim; as one popular slogan announced, "The whole nation rebuilds the capital!" 55 When the author recounted his journey from the thoughtless destruction of the capital during the Uprising to its restoration eight years later, he also summarized his political evolution from anti-communism to his eventual acceptance of communism. The military struggle, continued as a peaceful project (Reconstruction), was meant to justify and legitimize the social and cultural prominence of the war generation. This memoir presented the non-productive and belligerent ethics of noble classes as obsolete, destructive, and anachronistic, and contrasted them with the new post-heroic attitude of regular soldiers, sons of small farmers or industrial workers. In the case of the disabled war-veteran, this new attitude is particularly impressive: they worked to reconstruct the damaged country, but they also worked on themselves and the reconstruction of their impaired bodies. However, it is important to note that this is a Polish and highly politicized variant of global process of "deheroization." As David A. Gerber describes: "Chivalric values found heroism in the character inherent in a good man, who is fearless because he is noble. Postheroic assumptions associated with modern warfare find them in a peer group code of behavior that valorizes the individual's ability to respond effectively in war by doing a job in the face of fear, which is acknowledged to be inevitable. The measure of the individual lies in self-control, not in an honorable character." 56

\section{Battlefield Experiences versus Hardships of Postwar Life}

Interestingly, however, the majority of the eighteen texts gravitated toward military achievement, even if this achievement was reduced to a short episode in an author's biography. The subsequent twenty-five years of life in postwar conditions seemed to be of much less interest to the narratives, and take up less space in the confessions, even if the intention was to celebrate twenty-five years of postwar socialist prosperity embodied in the narratives of disabled men. This imbalance may result from the particular "framing" by Gaworski, who selected the narratives for the purpose of celebrating the military, soldierly experience rather than postwar life with its hardships. It is also possible that the authors preferred not to write too much about postwar reality because of political risks, as the true experiences of these years were at odds with the 
optimistic vision demanded by official authorities. ${ }^{57}$ The authors were surrounded by "military" narratives in books, films, radio, newspapers, and official politics of memory. This ubiquitous set of images and/or plots provided them with "ready-made" narrative blocks, while telling a more personal story could have been much more difficult. In addition, the authors could have preferred to put less stress on the emasculating reality of their disability and rather stress the masculinizing valor of their war service.

This attitude of particular reluctance was verbalized by one of the authors, who decided to focus exclusively on his prewar and front biography, in a rather harsh manner: "My further history is not interesting." ${ }^{58}$ Most authors stated that even though life after the war was challenging on a personal level, the political system, albeit with some difficulty, enabled war-disabled veterans to lead a satisfactory existence within the new formally classless society. Their postwar lived experience as war-disabled men with such life objectives as finding an appropriate job and sustaining a family was the story of new life, of the birth of a new man (they often highlighted the obvious fact that they had to overcome more obstacles than usual, while establishing their positions as legitimate breadwinners, husbands and/or fathers).

What was very characteristic was the internal imperative to silence any "unmanly" expression of pain, anger, and discomfort caused by the impairment. Internal suffering and weakness had to be moved out of sight of family or colleagues who could not see that a war veteran had problems with everyday functioning and that even simplest actions demanded extreme effort:

When socializing with colleagues or within the family, I always tried to be cheerful and to hide my suffering, my pain, or hurt. I did not complain about the enormous efforts in everyday life: putting a sock on, wearing a shoe, or adjusting the prosthesis costs me a lot of sweat. In private moments I was often confronting with myself, I have often rebelled against fate; I felt sorry that I am unable to dance, swim, fly or run, that I can't keep up with my friends, and-what is much worse-I cannot have a direct impact on my children's education. I cannot teach them sports, go on walks or trips, or do sightseeing or sports competitions. ${ }^{59}$

To make things worse, Polish society in the early postwar period was mainly rural and shared a traditional set of values, where the perception of the disabled body was marred by prejudice. The disabled body, incompleteness, "otherness," bodily deformation, and bodily malfunctions were often, and especially in rural communities, sources of superstitious anxiety. ${ }^{60}$ Memoirist Tadeusz Mazur was born in 1925 to a peasant family. In his memoir, he recalled a strong desire to join the army and wear a uniform. He believed that it could help him to escape the village life of a small farmer in the underdeveloped region. His dreams of emancipation were ruined when he lost his leg. After coming home, the local community expressed pity, grief, and even satisfaction that Tadeusz's ambitions were punished: "I felt as though I was a parasite with no future and my ambitions thwarted every single day." ${ }^{\prime 61}$

Disability studies scholars, such as David Serlin, have described the problem thus: war injuries were useful for the state ideological apparatus as "signs of extreme patri- 
otism," in which "disability is a kind of permanent uniform,"62 but social interactions and institutions continuously questioned veterans' masculinity. In a world where ability, agency, and independence are the markers of heterosexual hegemonic masculinity, disability is considered disgraceful for one's manhood. The disabled were, according to the dominant vision and popular imagination, emasculated and, in the best case, deserved pity. It is important to notice, however, that the "remasculinization story" outlined above was a local variant of a more typical narrative strategy of disabled veterans. Gerber argues that the narrative of "a feminized veteran, who overcomes the physical limitations and the rolelessness" was a widespread phenomenon elsewhere after World War II. The disabled veteran "becomes a real man once more" only by strength or endurance ${ }^{63}$ not only in state-socialist countries, but state socialism adapted these narratives to promote a particular version of a strong socialist masculinity forged in frontline experiences and reliable as a guardian of new postwar society.

War-Disabled Memoirs, at least partly, answered the demands of political propaganda and censorship, but gave only limited access to actual concerns and the sense of uncertainty war-disabled veterans experienced. The reader must search carefully and read between the lines to find traces of such doubts, tensions, or hesitations hidden by "manning up" stories:

I had vertigo and pain in my spine. Nevertheless, I was still working to help myself overcome the physical suffering and the even more harmful humiliation I faced in such public places as trams or streets. I kept believing that I was a useful citizen, and my work experience and everyday struggles were bricks in the construction of a prosperous and sturdy homeland. . . Sometimes during sports competitions, when I was very tired of moving, I noticed signs of sympathy or even pity [from others]. It was harmful; I was trying to withdraw, even if it was a momentary and unimportant impression concerning my colleagues and family; I tried to be always kind and cheerful with no sign of suffering or inconvenience.... I often revolted against myself in this internal struggle. ${ }^{64}$

Another author, Tadeusz Mazur, believed that military service offered much wider array of possibilities than he could have expected in his rural region, but the injury ruined his plans for the future. Due to his impairment he came back to his natal village and confronted with far worse personal situation than he could have ever imagined:

I became an invalid at the age of 20. I had no profession or training. For a long time, I was unable to accept this situation and I was often thinking about suicide. ... [After returning home, the author's family and neighbors] started hugging me, watching me carefully, kissing me and, what was even harder, they started asking me about the wound and inspecting my body. Then, they noticed my prosthesis. Women started to cry and one man said bitterly "Why on earth did you want to join the army?" Another one added: "How will you live without your leg?" A woman from the neighborhood stroked my head in pity. ... [My father said] that people like me can live exactly as others do and 
even succeed more than others. As an example, he mentioned a First World War invalid living prosperously nearby. ${ }^{65}$

These testimonies reveal the tensions between the imagined high and real low positions of war-disabled veterans. This discrepancy caused a sort of cognitive dissonance among the veterans, but they rarely recalled this feeling openly. The sense of uselessness as a constant threat is also visible in these testimonies: usefulness and masculinity overlap with each other, and the memoirists suggest that a man is a man as long as he proves he is useful, comparing everyday struggles with bricklaying, a true emblematic occupation in postwar Poland. ${ }^{66}$

The authors of the memoirs theoretically could have navigated between three main strategies in the (re)negotiations of gendered identity: reliance, reformulation, and rejection. ${ }^{67}$ In practice, however, they limited themselves to describing their identity as a reliable one and thus reinforced and supported the normative able-bodied vision of masculinity: an ongoing effort was made to fulfill the dominant ideals of normative, able-bodied masculinity as the only widely accepted and self-evident behavioral model in communist countries-and indeed, the only narratable model, codified in Soviet hagiography with examples provided by Nikolai Orlovsky and Boris Polevoy.

Throughout the collection, the war as a source of personal tragedy was blamed only once. In one of the memoirs, the author lapsed in his rendition of the biographical scheme and let himself express his feelings about the atrocities of war:

I would like to express my wish that future generations will not allow a war to happen again, and that they will not live in such hard times as we have; I hope that war will never happen again, here or anywhere else. Even though it ended many years ago, those who are disabled, or suffered in another way, will remember it until their last breath. I can feel it everywhere and all the time, even while I am sleeping. I often wake up suddenly as I dream about being wounded at the frontline. ${ }^{68}$

In fact, this short paragraph is unique in the whole collection, as it described diagnostic symptoms of post-traumatic stress disorder (PTSD) without naming it: the author was unaware of this medical qualification and made rhetorical use of his symptoms to send a warning message to the reader. ${ }^{69}$ His testimony contrasts with the vast majority of the authors, who considered war as a formative experience. For them, the most valuable personal traits were formed in the trenches and barracks, under enemy fire. The outstanding mental and physical strength that allowed one to pass through such a challenge was seen as necessary to overcome disability and to live in a socialist society in the twenty-five years since the end of the war.

There is an interesting paradox of continuity and change in veterans' biographies. Their lives rapidly changed because of their wounds and impairment, causing a sort of emasculation, but these dramatic personal circumstances contributed to wider and desired change of external conditions: the postwar peace and reconstruction instead offered new possibilities of regaining masculinity through continuous struggle, dili- 
gence, hard work, self-control, and overcoming external difficulties and internal weaknesses. A man is reborn.

\section{Conclusion}

The sources of legitimization located in war experience, military struggle, and martyrdom seemed largely to have dried up by the late 1960s. The cultural expressions related to the generational conflict following World War II is called in Polish historiography the "dispute over heroism." This dispute erupted in 1966 after Andrzej Wajda released his film Popioty (The ashes). According to popular understanding, it was at that time that the youth and intelligentsia (Polish "boomers") began to stand up against the politics of the communist state, and especially the Partisans. Young and well-educated "taunters" (szydercy) satirized and mocked military traditions, claiming they were outdated and out of place in a contemporary society with new problems such as rapid modernization, consumerism, changing lifestyles, and technological advancements. The Party "falcons," the Partisans, and a considerable segment of the older generation, who remembered the war and the occupation-and especially those who had been involved in the military struggle-opted, in contrast, for the celebration of martyrdom, military traditions, and the cult of patriotism as sources of identity, warrants of social stability, and an ideological framework to unite otherwise diverging social interests. ${ }^{70}$ This dispute left its mark on Polish culture with novels, films, and academic books considered today to be classics central to understanding Polish culture of the twentieth century. The works (novels, plays, films, essays) by such "taunters" as Sławomir Mrożek, Andrzej Munk, Tadeusz Konwicki, Andrzej Wajda, Miron Białoszewski, Janusz Głowacki, Anna Świrszczyńska, and Maria Janion belong to the core of twentieth-century national culture. ${ }^{71}$ This huge cultural revolt and vision of modernization was a reaction to the politics and political program of the Party in general and the Partisans, who believed that military experience was the foundation upon which national unity must rest, in particular. ${ }^{72}$ This discussion provided the cultural context of the analyzed publication, which defended a set of values attacked by "the taunters," "boomers," and "anti-socialist elements."

Natalia Jarska, who analyzes the discourse of masculinity and family in socialist Poland, sketched the social context for the ideological stance of the collection. She argues that in the 1960s, "male identities in state socialist Poland in question were negotiated." 73 She detects the appearance of a "plurality of forms" instead of a single dominating masculinity, including the development of: the caring father, the new romantic, the companion as opposed to the patriarch, the breadwinner, and the public man. This new diversity of social and cultural models allows us to assume that war-disabled veteran memoirs aimed to play an important role in negotiating this cultural shift. On the one hand, the memoirs reflected a new interest in the private sphere and family life, but, on the other hand, the narratives opted for traditional, strong, self-sufficient masculine models preferred and celebrated by party and state authorities. 
War-disability has been marginalized in Polish cultural memory and scholarship for many years. Its articulation was possible only within a particular ideological and political framing of pacifism, militarism, martyrdom, and mobilization. The collection of memoirs examined here is a unique documentation of the past. However, it is ideologically intertwined with the politics of memory and official propaganda, not to mention particular framing strategies used by the editor. Despite the imperative to conform to political aims and its inherent schematism, the collection subtly communicates some insights into the disabled memoirists' real-life experiences, problems, and dilemmas.

The reconstruction of the paradoxical position of the war-disabled is an important contribution in narrating the history of Polish masculinity. The memoirs analyzed here conveyed this history through the use of conventions typical for "memoir contests" of the 1960s and the Socialist Realism of earlier periods. The memoirs presented disabled masculinity as self-reliant and eager to overcome physical handicaps with discipline, mental strength, and diligence, shaped by and in the course of military service. The socialist state as well as its disabled citizens profited from these moral qualities formed in the trenches, barracks, and guerrilla shelters. This set of values established moral foundations for the interdependent personal development of a disabled man and economic progress of the state, both possible through hard work, which was a common denominator linking personal biographies and the progress of socialist society. The ideal model assumed unquestionable devotion to the socialist state, which endowed disabled men with opportunities for social advancement and rewarded their sacrifice in a number of ways: medals, materials, and organizational support. Military experience, which symbolically linked disabled veterans with their glorious ancestors, was highly valorized and praised: it was understood as a source of moral advantage and a foundation for a successful life in a postwar, socialist, and egalitarian society. Thus, the war-disabled represented an ostensibly highly valued model of masculinity and citizenship; however, their memoirs revealed the incongruities and paradoxes of their situation - the real life of the war-disabled veteran was a constant struggle to confirm his social and masculine role within the highly demanding context of the socialist society.

\section{$\diamond$ About the Author}

Wojciech Śmieja is an associate professor in the Faculty of Humanities at the University of Silesia in Katowice, Poland. His interests include Polish literature and culture of the twentieth and twenty-first centuries, gender and queer studies, and critical studies of men and masculinities. Śmieja participated in the four-year project, "Masculinities in Polish Culture and Literature of the 19th and 20th Century," which resulted in a three-volume anthology of texts (Forms of Masculinity 1, 2, 3, Warsaw 2018).

\section{$\diamond$ Notes}

1. Tadeusz Konwicki (22 June 1926-7 January 2015) was a Polish writer and film director. In the years 1952-1966, he was a member of Polish United Workers' Party. By the mid-1950s, 
Konwicki had become disillusioned by the communist regime in Poland and fell out of grace with the party. In the mid-1970s, he became one of the first Polish writers to publish illegally in the underground press: Kompleks polski [The Polish complex] (Zapis, 1977), transl. R. Lourie (Dalkey Archive Press, 1998) and Mała Apokalipsa [A minor apocalypse] (Warsaw: Niezależna Oficyna Wydawnicza, 1979), transl. R. Lourie (Dalkey Archive Press, 1999).

2. Tadeusz Konwicki, Sennik wspótczesny [A dreambook for our time] (1963), transl. by David Welsh (Boston: The MIT Press, 1970).

3. Łukasz Polniak, Patriotyzm wojskowy w PRL w latach 1956-1970 [Martial patriotism in Communist Poland 1956-1970] (Warsaw: TRIO, 2011), 13-21. The author claims that "martial patriotism" modified and enriched the official communist doctrine by adding some selected elements of national ideology and militarism. Thus, the ideology of martial patriotism was not an alternative for officially acclaimed Marxism, but it rather coexisted and mixed with the Party's official ideological stance. Martial patriotism was generally accepted as it was seen as a source of legitimization for the regime, which understood that Polish society rejected "internationalism" or "workers patriotism." In brief, the acceptance of "martial patriotism" was a pragmatic decision of the Party, which tried to establish a strong link with society through it.

4. Marcin Czerwiński, Przemiany obyczaju [Transformation of manners] (Warsaw: PIW, 1972), 121-126. See also Małgorzata Fidelis, "The Polish Thaw: Youth, Carnival, Domestic Revolution and Transnational Encounters" (NCEER Working Paper, 2004), https://www.ucis.pitt .edu/nceeer/2014_828-05g_Fidelis.pdf (accessed 12 May 2021); Małgorzata Fidelis, "The Other Marxists: Making Sense of International Student Revolts in Poland in Global Sixties," Zeitschrift für Ostmitteleuropa-Forschung 62, no. 3 (2013), 425-449, https://www.zfo-online.de/portal/in dex.php/zfo/article/view/9524/9523.

5. Raewyn W. Connell, Masculinities (Los Angeles: University of California Press, 1995), 79.

6. Natalia Jarska, "Men as Husbands and Fathers in Postwar Poland (1956-1975): Towards New Masculine Identities?" Men E Masculinities (March 2020): 1-22, https://doi.org/ 10.1177/1097184X20910492.

7. Historians and sociologists have described the institutional history of disability in Poland, but the history of disability and its relation to able-bodied masculinity still remains to be written. Marcin Garbat, Historia niepetnosprawności: geneza i rozwój rehablitacji, pomocy technicznych oraz wsparcia dla osób z niepetnosprawnościami [The history of disability: The origins and development of rehabilitation, technical support for the disabled people] (Gdynia: Novae Res, 2015). See also Zbigniew Głąb, "Studies in Social History of Disability in Poland: Approaches, Methods, Challenges," HISTORYKA: Studia Metodologiczne 50 (2020): 321-349, http:// doi.org/10.24425/hsm.2020.134808; Michael Rembis and Natalia Pamuła, "Disability Studies: A View from Humanities," Man-Disability—Society 31, no. 1 (Winter 2016): 5-23.

8. In this context it is worth mentioning that key disability studies writers recognized that the private dimension of lived experience of disabled men is underrepresented in both research and ego-documents, which often reproduced a public (masculine)-private (feminine) split. More personal accounts of disability/impairment began to emerge with autoethnographic writing in the 1980s and later. See Tom Shakespeare, "When Is a Man Not a Man? When He's Disabled," in Working with Men for Change, ed. Jim Wild (London: UCL Press, 1999), 58-99.

9. Dariusz Jarosz, "Wybrane aspekty polityki społecznej wobec kombatantów w latach 1945-1989" [Social policy and war-veterans 1945-1989: Selected problems], in Ojczynza obrońcy swemu: Weterani i kombatanci jako problem polityczny $i$ społeczny w Polsce w XX wieku [Veterans and combatants as a social and political issue in twentieth-century Poland], ed. Marek Kornat, Maciej Kruszyński, Tomasz Osiński, (Lublin: IPN, 2017), 191-216, here 192.

10. Jarosz, "Wybrane aspekty polityki społecznej wobec kombatantów w latach 1945-1989," 199. 
11. Ibid., 204-205.

12. Lucyna Ratkowska, "Postrzeganie i obrazowanie kalekiego ciała w pierwszych latach po II wojnie światowej" [Perception and Representation of the crippled body after World War II (early years)], Pamięć i Przyszłość [Memory and Future] 7 (1/10): 41-49, http://opip.megiteam .pl/files/0003/1264/KW_pip_nr_7_s41.pdf (accessed 8 April 2021).

13. War-disabled men were the ones who-profoundly injured-differed drastically from the dominant expectation for protective, able-bodied masculinity in postwar Poland. Demobilization had different meanings to different groups. Members of anti-communist guerilla groups could have a feeling of great loss, while those who joined the communist-oriented Polish Army had a relatively better position. (Their efforts were rewarded by, for example, the settling of veterans on farms in the former German territories.) Marcin Zaremba's study, Wielk a trwoga: Polska 1944-1947 (The great fear: Poland 1944-1947), suggests that war-disabled veterans could feel even more than others such emotions as exclusion, disappointment, and anger typical for the "veteran syndrome." The officially registered number of war-disabled reached 300,000 and "they were omnipresent: as beggars under the churches, in trams and trains, small traders, they were hanging around in market places and bazaars." Zaremba used press materials, documents, and police reports (war-disabled were suspected of committing not only petty crimes, but also anti-Semitic violence against Jews) to reconstruct the situation of disabled veterans. State support for the invalids and their families was insufficient and official policy of employment resulted in tensions between the able-bodied majority and the disabled veterans seen as "the privileged." Franciszek Bazydło, the head of the Association of War Disabled Veterans in this period, in a letter to the prime minister, complained on behalf of the association: "the situation of war-disabled, widows and war-orphans is dire. They are literally starving, suffer from cold, poverty and diseases, no wonder that death decimates the lines of the defenders of our Motherland." See Marcin Zaremba, Wielka trwoga: Polska 1944-1947 [The great fear: Poland 1944-1947] (Kraków: ZNAK 2012), 204-220, here 212-214.

14. Gaworski's biography: Joanna Siedlecka, Kryptonim "Liryka": Bezpieka wobec literatów [Code name Lyrics: Literary circles and secret services] (Warsaw: Prószynski i S-ka, 2008), 422-428.

15. Małgorzara Szpakowska, Chcieć i mieć: Samowiedza obyczajowa w Polsce czasu przemian [To want and to have: Self-consciousness of society in times of change] (Warsaw: WAB, 2003), 23.

16. Memoir contests have a long tradition in Polish culture and sociology. Pre-war Polish sociologist Józef Chałasiński studied the life and careers of workers and peasants, and compared Polish education, culture, and science to their US counterparts on the grounds of memoirs. His groundbreaking works encouraged numerous contests for memoirs in the 1930s. As Chałasiński continued his career in communist Poland, he and his students reinvigorated this prewar tradition. See Katherine Lebow, “Autobiography as Complaint: Polish Social Memoir Between the Two World Wars," Laboratorium: Russian Review of Social Research 6, no 3 (2014): 13-26.

17. Szpakowska, Chcieć i mieć, 30-31.

18. See Natalia Jarska's text in this issue: “Women's Work and Men: Generational and Class Dimensions of Men's Resistance to Women's Paid Employment in State Socialist Poland (1956-1980)."

19. Claire McCallum, "Scorched by the Fire of War: Masculinity, War Wounds and Disability in Soviet Visual Culture, 1941-65," Slavonic and East European Review vol. 93, no. 2 (April 2015), 251-285, here 270, https://doi.org/10.5699/slaveasteurorev2.93.2.0251 (accessed 8 April 2021).

20. Henryk Gaworski, "Wstęp" [Foreword], in Pamiętniki inwalidów wojennych [Wardisabled memoirs], ed. Henryk Gaworski (Warsaw: MON, 1971], 5-8, here 8. 
21. David A. Gerber, "Introduction: Finding Disabled Veterans in History," in Disabled Veterans in History: Enlarged and Revised Edition, ed. David A. Gerber (Ann Arbor: The University of Michigan Press, 2012), 1-55, here 1.

22. Gaworski, Wstęp, 5.

23. Szpakowska, Chcieć i mieć, 29.

24. Szpakowska, Chcieć i mieć, 23.

25. Józef Grenz, “Udział w trzech armiach” [Soldier of three armies], in Pamiętniki inwalidów wojennych, 66-81, here 81 .

26. Franciszek Bielawski, "Nie ma Kaszub bez Polonii" [No Kashubia without Polonia], in Pamiętniki inwalidów wojennych, 9-21, here 21.

27. Tadeusz Mazur, "Moja droga życiowa" [The way I live], in Pamiętniki inwalidów wojennych, 102-123, here 120.

28. The classical interpretation of Polish socialist realism is offered by Zbigniew Jarosiński in his Nadwiślański socrealizm [Polish socialist realism] (Warsaw: Instytut Badań Literackich, 1999).

29. Jarosiński, Nadwiślański socrealizm, 5.

30. Magdalena Piekara “Opowieść o prawdziwym człowieku—wizerunek Rosjan w polskiej prozie socrealistycznej" [Story of a real man-representation of Russians in Polish socialist realism], Przeglad Rusycystyczny [Russian Studies Review] 1/2 (2012): 140-157.

31. Lilya Kaganovsky, How the Soviet Man Was Unmade: Cultural Fantasy and Male Subjectivity under Stalin (Pittsburgh, PA: University of Pittsburgh Press, 2008).

32. Anna Krylova "'Healers of Wounded Souls': The Crisis of Private Life in Soviet Literature, 1944-1946," Journal of Modern History 73, no. 2 (2001): 307-331.

33. McCallum, "Scorched by the Fire of War," 254.

34. Alicja Wołodźko-Butkiewicz, "Radzieckie lektury obowiązkowe w Polsce w latach 1945-1953" [Soviet literature in Polish school curricula 1945-1953], Przegląd Rusycystyczny, $1 / 2$ (2012), 87-103, here 91.

35. Tadeusz Mazur, "Moja droga życiowa," 115.

36. This term is adapted from David T. Mitchell and Sharon L. Snyder, Narrative Prosthesis: Disability and Dependencies Discourses (Ann Arbor: The University of Michigan Press, 2000).

37. Anita P. Prażmowska, Poland: A Modern History (London: I.B Tauris, 2010), 192.

38. Joanna Wawrzyniak, ZBoWiD i pamięć drugiej wojny światowej 1949-1989 [Veterans, victims, and memory: The politics of the Second World War in Communist Poland (Studies in Contemporary History)] (Warsaw: TRIO, 2009), 105.

39. Wawrzyniak, ZBoWiD i pamięć drugiej wojny światowej 1949-1989, 105.

40. These discussions started with the publication of Jan Tomasz Gross's book, Neighbors: The Destruction of the Jewish Community in Jedwabne, Poland (Princeton, NJ: Princeton University Press, 2001).

41. Jan Olbrycht, "Konfrontacje" [Confrontations], in Pamiętniki inwalidów wojennych, 202232 , here 227

42. Tadeusz Mazur, "Moja droga życiowa," 115.

43. Jan Olbrycht, "Konfrontacje," 202.

44. Wawrzyniak, ZBoWiD i pamięć drugiej wojny światowej 1949-1989, 31.

45. Wawrzyniak, ZBoWiD i pamięć drugiej wojny światowej 1949-1989, 34.

46. Mikołaj Gliński, "A Memoir of the Warsaw Uprising," https://culture.pl/en/work/amemoir-of-the-warsaw-uprising-miron-bialoszewski (accessed 8 April 2021).

47. Piotr Sobolczyk, "Queering the Warsaw Uprising (with A Little Help from Miron Białoszewski)," Studia Humanistyczne AGH 14/2 (2015): 193-213, http://bazhum.muzhp.pl/ media//files/Studia_Humanistyczne_AGH/Studia_Humanistyczne_AGH-r2015-t14-n2/ 
Studia_Humanistyczne_AGH-r2015-t14-n2-s193-213/Studia_Humanistyczne_AGH-r2015-t14n2-s193-213.pdf (accessed 8 April 2021).

48. Gaworski, Wstęp, 9.

49. Zbigniew Załuski, "Zamiast uzasadnienia” [Instead of justification], in Zbigniew Załuski, Siedem polskich grzechów głównych: Nieśmieszne igraszki [Seven Polish deadly sins. Unfunny games] (Warsaw: Książka i Wiedza, 1973), 8. See also Zbigniew Załuski, "Sztafeta pokoleń: O czym mówimy z młodzieżą" [Between generations: What are we talking about with the youth], in Zbowidowcy: Tradycje i zadania [Veterans: Traditions and tasks], ed. Mikołaj Łomacki and Jadwiga Szulc-Lyskowa (Warsaw: Książka i Wiedza, 1969), 355-367.

50. Anthony Kemp-Welch, Poland under Communism: A Cold War History (London: Cambridge University Press, 2008), 158.

51. Gaworski, Wstęp, 9.

52. See Adam Leszczyński, Ludowa historia Polski [A people's history of Poland] (Warsaw: WAB, 2020).

53. See Jacek Ślusarczyk, Ruch obrońców pokoju w latach 1948-1989: Kompendium [Movement for the defence of peace, 1948-1989], (Warsaw: Instytut Studiów Politycznych Polskiej Akademii Nauk,1996).

54. Waldemar Wojszwili, "Zasadzka" [The ambush], in Pamiętniki inwalidów wojennych, 251-265, here 264.

55. Grzegorz Piątek, Najlepsze Miasto świata, Warszawa w odbudowie 1944-1949 [The best city in the world: The reconstruction of Warsaw 1944-1949] (Warsaw: WAB, 2020).

56. Gerber, "Introduction: Finding Disabled Veterans in History," 5.

57. The official Polish optimism was similar to that of the Soviet Union, where the press "hailed the Soviet treatment of disabled veterans as a hallmark of the progressive, inclusive, and technologically advanced nature of Soviet society," but in reality support was minimal and "crippled" veterans were abandoned. McCallum, "Scorched by the Fire of War," 264.

58. Julian Kardaś, "W obronie władzy ludowej” [In defense of the authority of the people], in Pamiętniki inwalidów wojennych, 186-201, here 201.

59. Jerzy Hejduk, "Los człowieka" [Destiny of a man], in Pamiętniki inwalidów wojennych, 46-65, here 64-65.

60. See Ewelina Szpak, "Chory człowiek jest wtedy jak coś go boli." Społeczno-kulturowa historia $z$ drowia i choroby na wsi w Polsce Ludowej [Socio-cultural history of health and disease in rural Poland 1945-1989], (Warsaw: IH PAN, 2018), 290-303.

61. Mazur, "Moja droga życiowa," 117.

62. David Serlin, "The Other Arms Race," in The Disability Studies Reader, 2nd edition, ed. Lennard J. Davis (New York: Routledge, 2006), 49-66, here 54.

63. David A. Gerber, "The Continuing Relevance of the Study of Disabled Veterans," in Disabled Veterans in History: Enlarged and Revised Edition, ed. David A. Gerber (Ann Arbor: The University of Michigan Press, 2012), ix-xxiii, here xiv.

64. Hejduk, "Los człowieka," 63-64.

65. Mazur, "Moja droga życiowa," 115-116.

66. See Ewa Toniak, Olbrzymki: Kobiety $i$ socrealizm [Giantesses: Women and socialist realism] (Kraków: Ha!art, 2008), 11-38.

67. Steve Robertson, Lee Monaghan, and Kris Southby, “Disability, Embodiment and Masculinities: A Complex Matrix," in Routledge International Handbook of Masculinity Studies, eds L. Gottzen, Ulf Mellström, and Tamara Shefer (New York: Routledge, 2020), 146-157, here 155.

68. Florian Szabłowski, W natarciu! [In attack!], in Pamiętniki inwalidów wojennych, 304-315, here 314 . 
69. The first Polish scientific publications on a related topic appeared in the 1950s and were focused on the research of former concentration camps prisoners (KZ-Syndrome). The research team from the Department of Psychiatry of Collegium Medicum (Jagiellonian University in Cracow) headed by Professor Antoni Kępiński made a very extensive description of KZSyndrome, but scientific interests were focused on prisoners exclusively, and no regular research concentrated on PTSD as a problem concerning war-veterans. See Krzysztof Rutkowski and Edyta Dembińska, "Post-War Research on Post-Traumatic Stress Disorder. Part I. Research before 1989," http://www.psychiatriapolska.pl/uploads/onlinefirst/ENGverRutkowski_Psy chiatrPolOnlineFirstNr21.pdf (http://dx.doi.org/10.12740/PP/OnlineFirst/41232) (accessed 8 April 2021).

70. “A CIA round-up report 'Restless Youth' (from 1968) noted a generation gap in Poland. Half the population was under twenty-five but these younger Poles did not favor a return to private ownership or the pre-war social system. They appeared most 'to oppose the stagnation and lack of movement, the exclusiveness and corruption of the establishment'. Communist ideology was seen as irrelevant: 'a dead letter with only its institutional forms still prevailing'. Like most ruling communist parties, the Polish Party was seen as a 'core of a stagnant society rather than a dynamic stimulant to change'. In attitudes, 'students favoured a form of WestEuropean social democracy', a non-sectarian approach to religion and experimental freedom in the arts. Their nationalism was tempered by 'vague feelings of supra-nationalism and a strong allegiance to Europe as an entity.' It was this last concern that East European leaders, including Gomułka, began to address. The generational conflict had an enormous impact on the whole society. It was not limited to such elite-groups as students and young intellectuals, even working class youth had enough. It is not an accident that future leader, Lech Walesa, shared this experience: 'His generation, reaching adulthood in the sixties, was 'ready for dialogue and compromise [but] not very receptive to officially-launched doctrines, and mistrustful of empty declarations and senseless slogans, quite knowledgeable on general subjects, but lacking a full knowledge of the system under which they live."' Anthony Kemp-Welch, Poland under Communism, 170-171.

71. See, for example, Adam Zamoyski, The Polish Way: A Thousand-Year History of the Poles and Their Culture (London: John Murray Publishers Ltd., 1987), 386-389.

72. See, for example, Maria Piwińska, Legenda Romantyczna i prześmiewcy [Romantic legends and the taunters] (Warsaw: PIW, 1973); or Maria Janion, Płacz generała: Eseje o wojnie [General's tears: Essays on war] (Warsaw: SIC!, 1998).

73. Jarska, "Men as Husbands and Fathers in Postwar Poland 1956-1975," 17. 